\title{
Effect Of Rapid Solidification On Mechanical Properties Of Free Machining Lead Free Aluminum Alloys For Improved Machinability
}

\author{
Rizk Mostafa Shalaby, Nermin Ali Abdelhakim and Mustafa Kamal \\ Metal Physics Laboratory, Physics Department, Faculty of Science, Mansoura University, Mansoura, Egypt, \\ P.O.Box: 35516. \\ E-mails: rizk2002@mans.edu.eg,drnerminsayed@yahoo.com,kamal42200274@yahoo.com
}

\begin{abstract}
There have been very few reports describing the free machining lead free aluminum alloys containing minimal amounts of tin and indium melt spun process. Our paper describes the effect of fundamental factors on the machinability of free machining lead free aluminum alloys rapidly solidified from melt. Structural and thermal properties have been investigated by x-ray diffraction (XRD) and differential scanning calorimetry (DSC) techniques. Tensile test machine used in studies the mechanical properties such as ultimate tensile strength, elastic constants, yield strength and critical shear stress for Al-Zn$\mathrm{Sn}$-In alloys. It is noticed that mechanical and thermal properties attributed to fine grained structure, reduced levels of segregation and presence of new intermetallic compounds (IMC) such as AIZn and SnZn due to high casting rate by rapid solidification processes. The determination of mechanical properties was suggested to be attributed to the gradual increase of $\alpha$-Al crystals. We evaluated the tensile properties using tensile test machine of the melt-spun ribbons at varied stress-strain rates to determine the underlying deformation mechanisms.Critical shear stress (CSS) was also calculated .It was found that it is equal to $9.29 \mathrm{GPa}$ for annealed ribbons at $262{ }^{\circ} \mathrm{C}$ for $9 \mathrm{hrs}$. The results showed that several combination of tensile strength, yield strength ,elastic moduli can be generated from Al- $0.1 \mathrm{wt} \% \mathrm{Zn}-1.5 \mathrm{wt} \% \mathrm{Sn}-1.63 \mathrm{wt} \%$ In alloys before and after heat treatment at $\left(262{ }^{\circ} \mathrm{C}\right.$ for $\left.3,6,9 \mathrm{hrs}\right)$ to meet the needs of free machining aluminum alloy applications.
\end{abstract}

\section{Indexing terms/Keywords}

Free machining alloys, rapid solidification, microstructure, mechanical properties.

\section{INTRODUCTION}

It is well known that metallic liquids are extremely unstable and crystallize almost immediately at temperatures lower than melting point. Since recorded history, practical metallic materials have been made by taking advantage of the crystallization principle; however, progress with this approach was severely limited because of the requirements of the thermodynamic equilibrium conditions as well as the necessity of translation and rotation symmetry. The use of materials with low specific weight is an effective way of reducing the weight of structures. Aluminum alloys are among the most commonly used lightweight metallic materials as they offer a number of different interesting mechanical and thermal properties. In addition, they are relatively easy to shape metals, especially in material removal processes, such as machining [1]. Machinability is a consideration in the materials selection process for automatic screw machine parts. The ease with which a metal can be machined is one of the principle factors affecting a product's utility, quality and cost [2]. Free machining aluminum alloys used for machining operations such as drilling, milling, turning, etc. This means that if the factors against the cutting tools are low then the melt-spun ribbons used in this work are easily machinable. These alloys typically include free machining constituents such as lead, tin, indium and bismuth for improved machinability. These constituents form low melting point compounds which readily soften or melt These constituents form low melting point compounds which readily melt or soften due to the friction heat created during machining[3].These elements have a limited solubility in the aluminum solid solution and form soft ,low melting phases supporting chip breakage and lubricate the tool. Generally ,chip breaking alloying elements have to show the following properties :(1) these elements are insoluble in the aluminum matrix , (2) have lower melting point in comparison to the aluminum , (3)don`t form intermetallic compounds with aluminum or other alloying compounds , (4) have a lower hardness than the aluminum matrix. Lead, bismuth, tin, indium and others meet all or partially these requirements [4]. During turning, an extensive plastic deformation occurs in the shear plane which causes the breaking of less ductile material [4]. Furthermore, generated heat due to the massive plastic deformation leads to thermal expansion of the inclusions against the aluminum matrix and thus vacancy defect building [5,6]. Additionally, inclusions should begin to melt at theses temperatures [7]. through the increased volume and by the edge effect generated tension ,the ductility of the material in the working zone causes the easy breaking of the chips[5,8-9].During machining, free-machining alloys generate small chips or curls which are easily collected and do not interfere with the machining process. It is essential that these free machining aluminum alloys form these small chips or curls for proper machining.

In brief, such small and short chips are substantial for a higher productivity and reduced cycle time, resulting in cost and time savings [10]. Therefore the current research paper focuses on chip breaking inclusions in machining aluminum alloys where lead is substituted by tin and indium.

\section{EXPERIMENTAL PROCEDURES}

The experiment used variations of free machining lead free aluminum alloys as used in table (1). 
Table 1. Designated composition of the free machining lead free aluminum alloys

\begin{tabular}{|c|c|c|c|c|}
\hline \multirow{2}{*}{ Free machining alloy } & \multicolumn{4}{|c|}{ Element content (wt\%) } \\
\cline { 2 - 5 } & Al & Zn & Sn & In \\
\hline Al-Zn-Sn-In & 99.48 & 0.1 & 0.2 & 0.22 \\
\hline Al-Zn-Sn-In & 98.86 & 0.1 & 0.5 & 0.54 \\
\hline Al-Zn-Sn-In & 97.88 & 0.1 & 1 & 1.02 \\
\hline Al-Zn-Sn-In & 96.77 & 0.1 & 1.5 & 1.63 \\
\hline
\end{tabular}

\subsection{MATERIALS AND SAMPLE PREPARATION}

Rapidly solidified Al-Zn-Sn-In alloys have been produced by a single copper roller melt-spinning technique [11]. Required quantities of the used aluminum, zinc, tin, indium metals of $99.999 \%$ purity were weighed out and melted in a porcelain crucible. After the alloys were molten, theme It was thoroughly agitated to effect homogenization. The casting was done in air at a melt temperature of $660^{\circ} \mathrm{C}$. The speed of the copper wheel was fixed at $2900 \mathrm{rpm}$; which corresponds to a linear speed of $30.4 \mathrm{~m} / \mathrm{s}$.

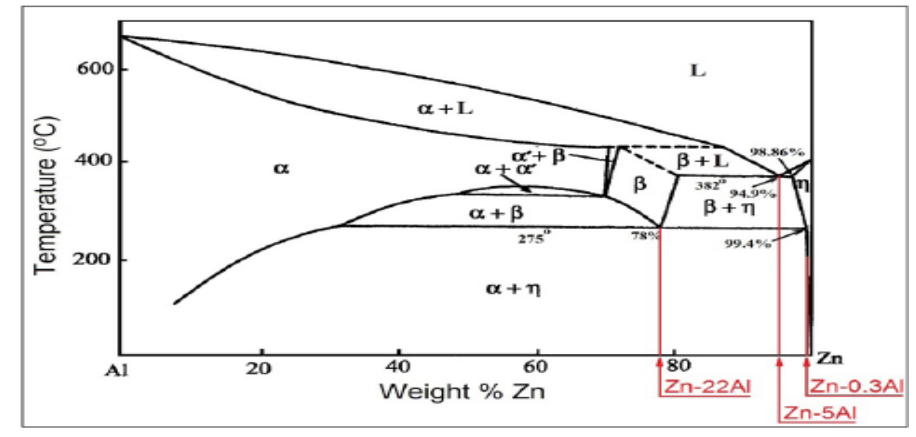

Fig 1: Binary Al-Zn phase diagram [12]

\subsection{SAMPLE CHARACTERIZATION}

A variety of techniques was carried out to characterize the crystallographic, and transformation features of the melt spun ribbons including $\mathrm{x}$-ray diffraction. The $\mathrm{x}$-ray diffraction study was carried out using $\mathrm{Cu}$ Ka radiation at room temperature. The microstructure analysis was carried out on a scanning electron microscope (SEM) of type (JEOL JSM-6510LV, Japan) operate at $30 \mathrm{KV}$ with high resolution $3 \mathrm{~nm}$. The melting temperature of these alloys was determined by differential scanning calorimetry, with a heating rate $10 \mathrm{~K} / \mathrm{min}[13]$.

\subsection{MECHANICAL MEASUREMENTS}

\subsubsection{Tensile Test Machine}

In tensile testing, sample to be tested is machined to standard dimensions. Generally $40 \mathrm{~mm}$ length and $2 \mathrm{~mm}$ width round test specimen as shown below is used for the test.

\section{Photographic view}

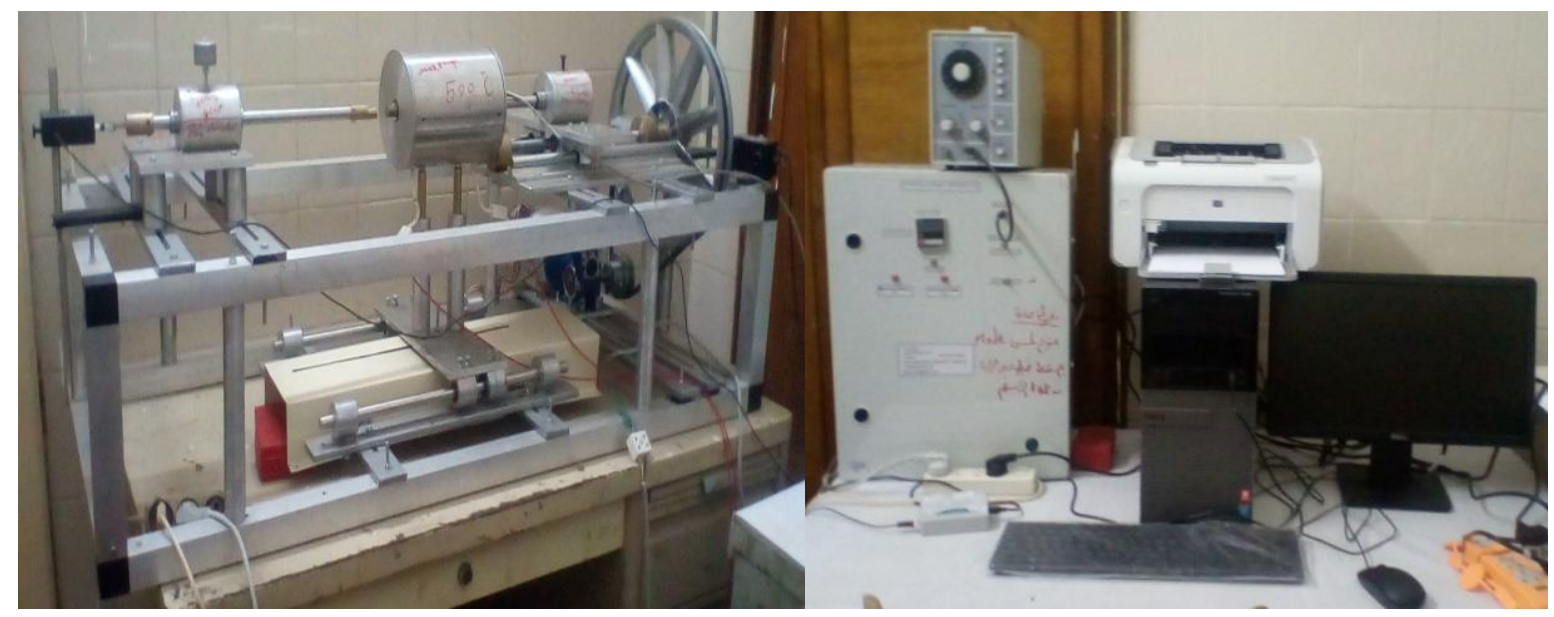




\section{Sample dimensions}

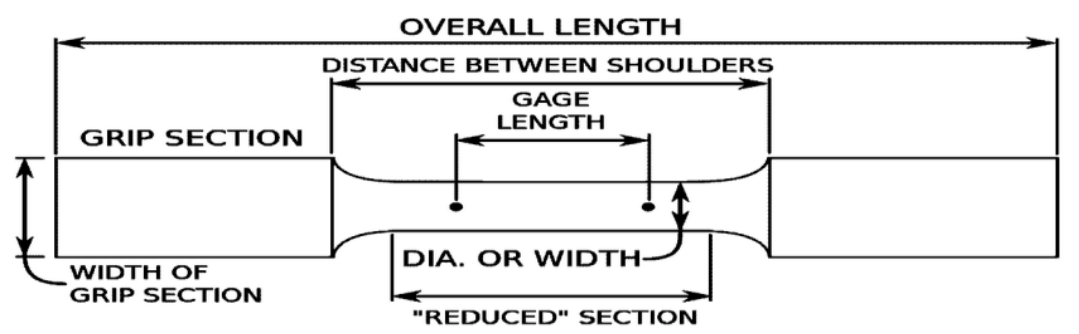

Fig 2:Tensile test machine

The specimen is gauge marked with a center punch, scribe marks or drawn with ink. The purpose of these gage marks is to determine the elongation. The testing machine is equipped with a loading system of mechanical. The specimen is fitted in the laws of the testing machine and subjected to a tensile load. The applied load (stress) and the resulting elongation (strain) of the specimen are measured computerized. The process is repeated with increased load until the specimen breaks. Using these data a stress- strain diagram is plotted using computer set up contains software program to find out tensile properties.

\subsubsection{Microhardness}

Vickers Hardness Test is a standard method for measuring the hardness of metals, particularly those with extremely hard surfaces: the surface is subjected to a standard pressure for a standard length of time by means of a pyramid-shaped diamond. The diagonal of the resulting indention is measured under a microscope and the Vickers Hardness value read from a conversion table Vickers hardness is a measure of the hardness of a material, calculated from the size of an impression produced under load by a pyramid-shaped diamond indenter. Devised in the 1920s by engineers at Vickers, Ltd., in the United Kingdom, the diamond pyramid hardness test, as it also became known, permitted the establishment of a continuous scale of comparable numbers that accurately reflected the wide range of hardness found in steels.

The indenter employed in the Vickers test is a square-based pyramid whose opposite sides meet at the apex at an angle of $136^{\circ}$. The diamond is pressed into the surface of the material at loads ranging up to approximately 120 kilograms-force, and the size of the impression (usually no more than $0.5 \mathrm{~mm}$ ) is measured with the aid of a calibrated microscope. The Vickers number $\left(\mathrm{H}_{\mathrm{V}}\right)$ is calculated using the following formula:

$$
\mathrm{H}_{\mathrm{v}}=\frac{2 \mathrm{~F} \operatorname{Sin} \frac{186^{\mathrm{u}}}{\mathrm{z}}}{\mathrm{d}^{\mathrm{2}}}, \quad \mathrm{H}_{\mathrm{v}}=1.854 \frac{\mathrm{F}}{\mathrm{d}^{2}} \text { approximately }
$$

With $(F)$ being the applied load (measured in kilograms-force), $d$ the arithmetic mean of the two diagonals, $d_{1}$ and $d_{2}$ in $\mathrm{mm}$ and $\mathrm{d}^{2}$ the area of the indentation (measured in square millimeters). The applied load is usually specified when $\mathrm{H}_{\mathrm{v}}$ is cited.

\section{RESULT AND DISCUSSION}

\subsection{Structure Properties}

\subsubsection{Structure}

Metal alloys prepared using Rapid solidified from melt was reported by Pol Duwez et al [13]. The X-ray diffraction (XRD) patterns of the melt-spun Al-Zn-Sn-In ribbons rapidly solidified from melt at $\left(660{ }^{\circ} \mathrm{C}\right)$. The $\mathrm{X}$-ray analysis of the alloys show the existence of four kinds of phases the Al-phase with face centered cubic structure, $\mathrm{Al}_{0.403} \mathrm{Zn}_{0.597}$ with anorthic structure, In-phase with tetragonal structure and $\mathrm{SnZn}$ phase with hexagonal structure. From $\mathrm{X}$-ray diffraction patterns of Al-Zn-Sn-In alloys as indicates show that two phases of the structure face centered cubic $\alpha$ $\mathrm{Al}$ and intermetallic compounds $\mathrm{Al}_{0.403} \mathrm{Zn}_{0.597}$ at $2 \theta=38.4662,44.6465,65.0767,78.1715,82.3878,99.0322$ of alloys as shown in Figures $(3,4)$. From $\mathrm{x}$-ray analysis, adding $\mathrm{Sn}$ and $\mathrm{In}$ content to $\mathrm{Al}-0.1 \mathrm{wt} \% \mathrm{Zn}$ alloy produced a change in its matrix microstructure (particle size, lattice parameters and lattice distortion) and the shape of formed phases such as peak intensity, peak broadness and peak position. A cubic crystal gives diffraction lines whose $\sin 2 \theta$ values satisfy the following equation obtained by combining the Bragg law with the plane-spacing equation for the cubic system:

$$
\frac{\sin ^{2} \theta}{(\mathrm{h} 2+\mathrm{k} 2+12)}=\frac{\lambda^{2}}{4 a^{2}}
$$

The lattice parameter a calculated from the $\sin 2 \theta$ value for the highest-angle line, it was found approximately the same value $(a=4.054 \AA$ It is also indicated that the number of atoms / unit cell is the same approximately (3.8 atoms/ unit cell). 

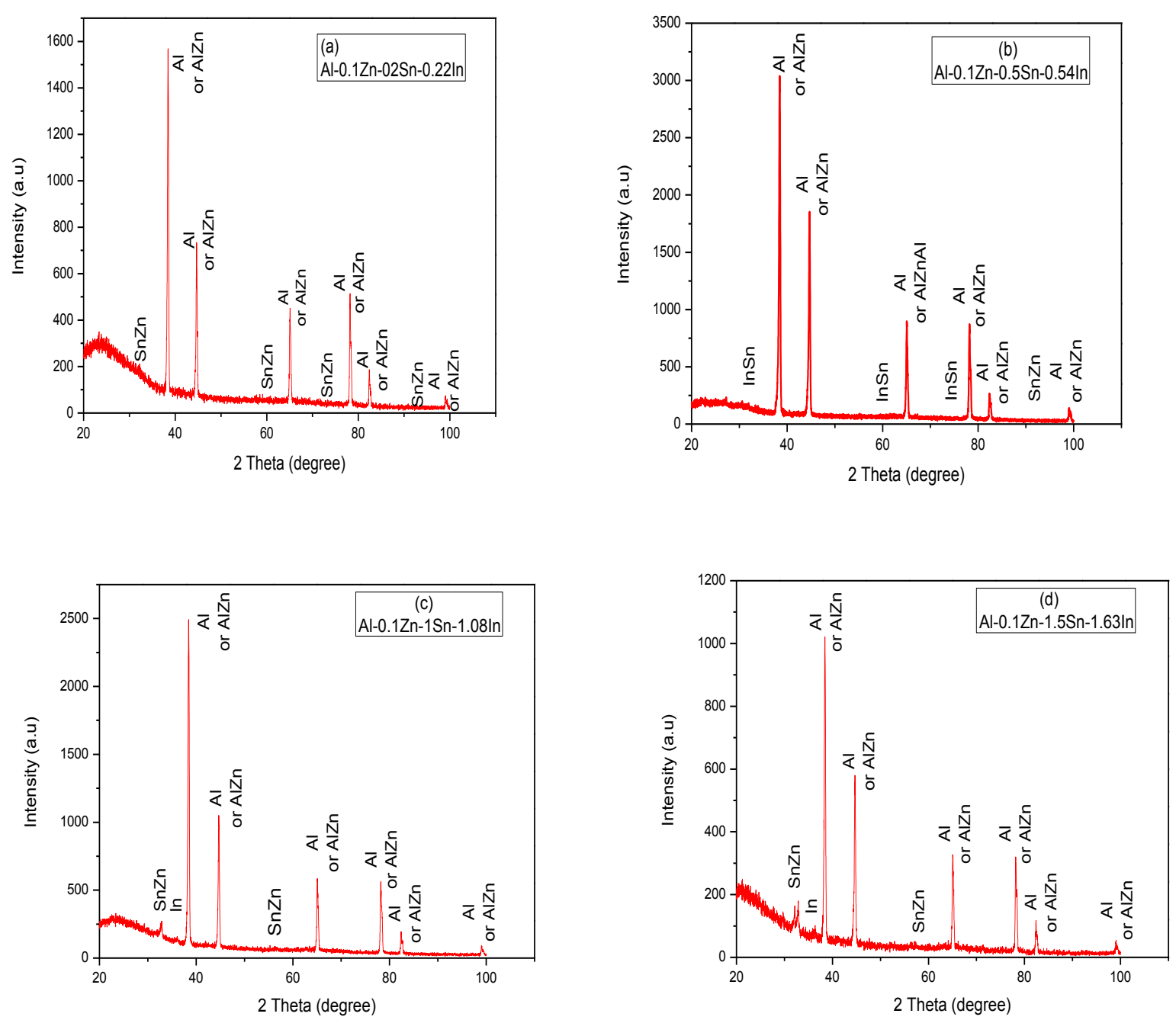

Fig 3: The XRD patterns of free machining (a) Al-0.1Zn-0.2Sn-0.22In, (b) Al-0.1 Zn-0.5 Sn-0.54 In, (c) Al-0.1 Zn-1 Sn-1.08 In, (d) Al-0.1 Zn-1.5 Sn-1.63 In alloys
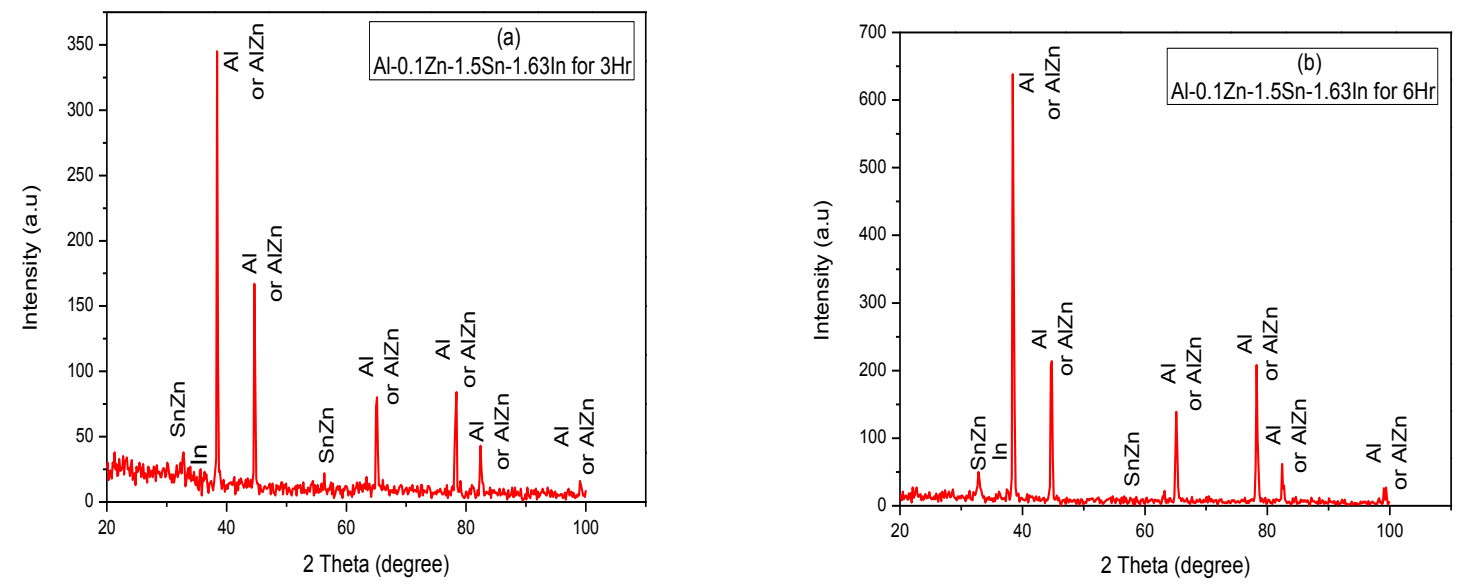


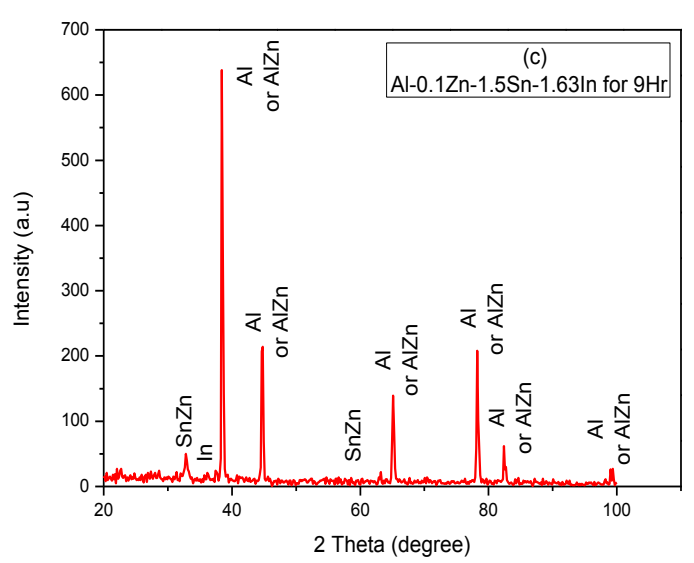

Fig 4: The XRD patterns of heat treatable free machining (a) Al-0.1Zn-1.5 Sn-1.63 In for 3hr, (b) Al-0.1 Zn-1.5 Sn$1.63 \mathrm{In}$ for $6 \mathrm{hr}$, (c) Al-0.1 Zn-1.5 Sn-1.63 In for $9 \mathrm{hr}$ alloys To determine information about the local lattice deformation and crystallite size $\left(D_{\text {eff }}\right)$ in $\alpha-$ Al phases by the next formula [15]:

$$
\mathrm{B}=\frac{1}{\mathrm{D}_{\text {eff }}}+5<\varepsilon^{2}>^{1 / 2} \operatorname{Sin} \frac{\theta}{\lambda}
$$

The $\frac{1}{\text { Deff }}$ and $5<\varepsilon^{2}>^{1 / 2}$ parameters are given in table $2(a, b)$, Lattice distortions for aluminum phase in all the meltspun ribbons are very low as indicating in the table (2). This supports the optimum formation of face-centered cubic structure.

Table 2a. The details of the XRD analysis and lattice disorder of free machining aluminum alloys

\begin{tabular}{|c|c|c|c|c|c|c|}
\hline Melt-spun ribbons & Phases & Crystal system & $\begin{array}{c}\mathbf{a} \\
\text { of } \mathrm{Al} \text { phase } \\
\left(\mathbf{A}^{\mathrm{O}}\right)\end{array}$ & $\begin{array}{l}\text { Particle } \\
\text { size } \\
\text { (nm) }\end{array}$ & $\begin{array}{l}1 / D_{\text {eff }} \\
\left(A^{0-1}\right)\end{array}$ & $5<\varepsilon^{2}>^{1 / 2}$ \\
\hline $\begin{array}{c}\text { Al-0.1\%Zn-1.5\%Sn- } \\
1.63 \% \text { In (for } 3 \text { hr.) }\end{array}$ & $\begin{array}{c}\mathrm{Al} \\
\mathrm{AIZn}, \mathrm{SnZn},\end{array}$ & $\begin{array}{c}\text { FCC } \\
\text { Anorthic, Hexagonal, } \\
\text { Tetragonal }\end{array}$ & 4.05558 & 369.31 & 0.0022 & 0.000763 \\
\hline $\begin{array}{c}\mathrm{Al}-0.1 \% \mathrm{Zn}-1.5 \% \mathrm{Sn}- \\
1.63 \% \mathrm{In} \text { (for } 6 \mathrm{hr} . \text { ) }\end{array}$ & $\begin{array}{c}\mathrm{Al} \\
\mathrm{AlZn}, \mathrm{SnZn},\end{array}$ & $\begin{array}{c}\text { FCC } \\
\text { Anorthic, Hexagonal, } \\
\text { Tetragonal }\end{array}$ & 4.0558 & 325.48 & 0.0023 & 0.000916 \\
\hline $\begin{array}{c}\mathrm{Al}-0.1 \% \mathrm{Zn}-1.5 \% \mathrm{Sn}- \\
1.63 \% \mathrm{In} \text { (for } 9 \mathrm{hr} .)\end{array}$ & $\begin{array}{c}\mathrm{Al} \\
\mathrm{AlZn}, \mathrm{SnZn},\end{array}$ & $\begin{array}{c}\text { FCC } \\
\text { Anorthic, Hexagonal, } \\
\text { Tetragonal }\end{array}$ & 4.0435 & 285.25 & 0.0027 & 0.001066 \\
\hline
\end{tabular}


Table $2 \mathrm{~b}$. The details of the XRD analysis and lattice of free machining aluminum alloys heat treatable alloys at $262^{\circ} \mathrm{C}$

\begin{tabular}{|c|c|c|c|c|c|c|}
\hline $\begin{array}{c}\text { Al- } 0.1 \% Z n-0.2 \% \text { Sn- } \\
0.22 \% \ln \end{array}$ & $\begin{array}{c}\mathrm{Al} \\
\mathrm{AlZn}, \mathrm{SnZn}\end{array}$ & $\begin{array}{c}\text { FCC } \\
\text { Anorthic, Hexagonal }\end{array}$ & 4.0535 & 276.21 & 0.0021 & 0.000813 \\
\hline $\begin{array}{c}\text { Al- } 0.1 \% Z n-0.5 \% \text { Sn- } \\
0.54 \% \text { In }\end{array}$ & $\begin{array}{c}\mathrm{Al} \\
\mathrm{AlZn}, \mathrm{SnZn}\end{array}$ & $\begin{array}{c}\text { FCC } \\
\text { Anorthic, Hexagonal, }\end{array}$ & 4.0552 & 246.41 & 0.0028 & 0.00118 \\
\hline $\begin{array}{c}\text { Al-0.1\%Zn-1\%Sn- } \\
1.02 \% \text { In }\end{array}$ & $\begin{array}{c}\mathrm{Al} \\
\mathrm{AlZn}, \mathrm{SnZn}, \\
\ln \end{array}$ & $\begin{array}{c}\text { FCC } \\
\text { Anorthic, Hexagonal, } \\
\text { Tetragonal }\end{array}$ & 4.0547 & 281.99 & 0.0027 & 0.001161 \\
\hline $\begin{array}{c}\text { Al-0.1\%Zn-1.5\%Sn- } \\
1.63 \% \text { In }\end{array}$ & $\begin{array}{c}\mathrm{Al} \\
\underset{\mathrm{In}}{\mathrm{AlZn}, \mathrm{SnZn}}\end{array}$ & $\begin{array}{c}\text { FCC } \\
\text { Anorthic, Hexagonal, } \\
\text { Tetragonal }\end{array}$ & 4.0547 & 256.36 & 0.0023 & 0.000909 \\
\hline Melt-spun ribbons & Phases & Crystal system & $\begin{array}{c}\mathbf{a} \\
\text { of Al phase } \\
\stackrel{\AA}{\mathbf{A}})\end{array}$ & $\begin{array}{l}\text { Particle } \\
\text { size } \\
\text { (nm) }\end{array}$ & $\begin{array}{l}1 / D_{\text {eff }} \\
\left(A^{0-1}\right)\end{array}$ & $5<\varepsilon^{2}>^{1 / 2}$ \\
\hline
\end{tabular}

\subsubsection{Microstructure Analysis}

The microstructures of Al-Zn-Sn-In alloys before and after heat treatment are shown in figs $(5,6)$. As shown in fig $(5 a)$, the microstructure of free machining aluminum alloy Al-Zn-Sn-In is irregular grains. When the content of tin and indium increasing the crystal grains in fig 5 (b, c) are shaped long and short flakes like. With the content of tin and indium increasing more, the microstructure becomes finer as shown in fig (5d) and its distribution becomes more homogeneous. Fig 6 show the microstructure of free machining aluminum alloy Al-Zn-Sn-In after heat treatment at $262{ }^{\circ} \mathrm{C}$ at different times 3, 6, 9 hrs. As shown in fig 6 the IMCs of AIZn and SnZn phase (gray regions) begins to appear and increases evidently in the microstructure with time of heat treatment increasing. The finer and more homogeneous microstructure leads to suitable effect on the mechanical properties of free machining aluminum alloys.

(a)

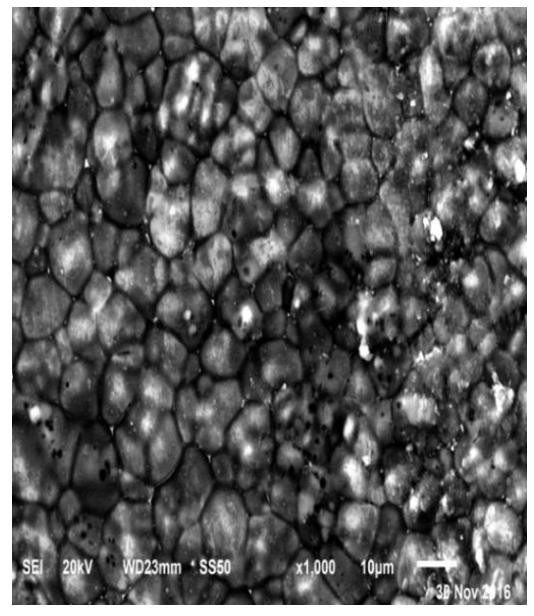

Al-0.1wt\%Zn-0.2wt\%Sn-0.22wt\%ln (b)

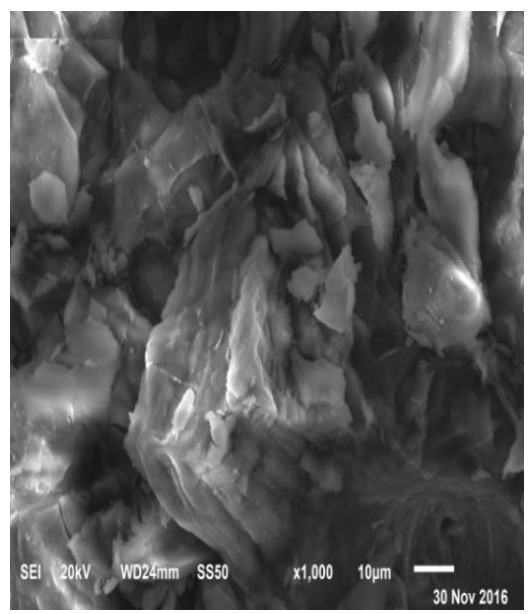

Al-0.1wt\%Zn-0.5wt\%Sn-0.54wt\%ln (c)

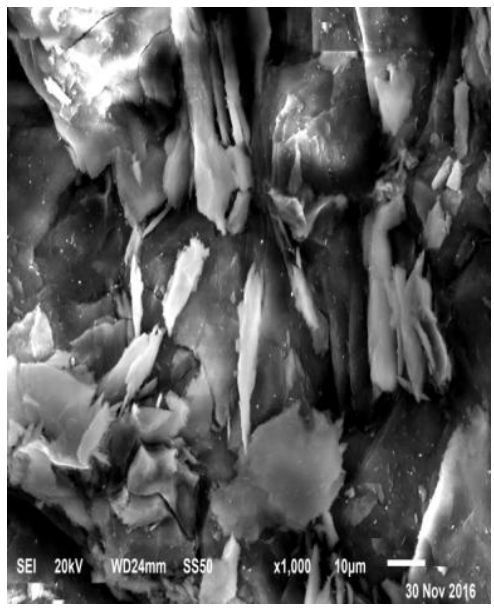

Al-0.1wt\%Zn-1wt\%Sn-1.02wt\%ln 
(d)

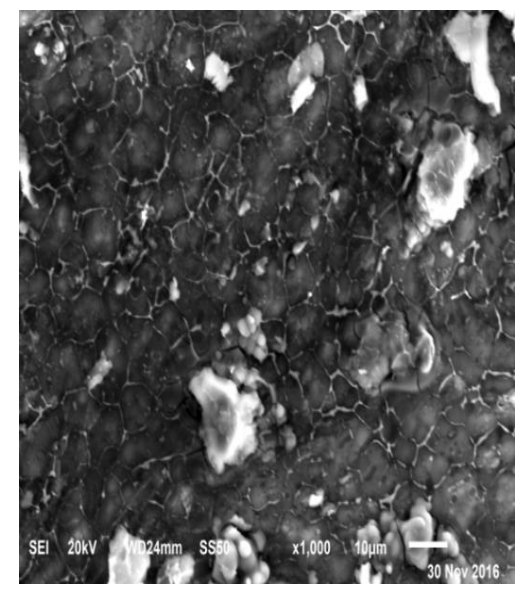

Al-0.1wt\%Zn-1.5wt\%Sn-1.63wt\%ln

Fig 5: SEM micrograph of free machining (a) Al-0.1 Zn-0.2 Sn-0.22 In ,(b) Al-0.1 Zn-0.5 Sn-0.54 In , (c) Al-0.1 Zn-1 Sn-1.08 In, (d) Al-0.1 Zn-1.5 Sn-1.63 In alloys

(a)

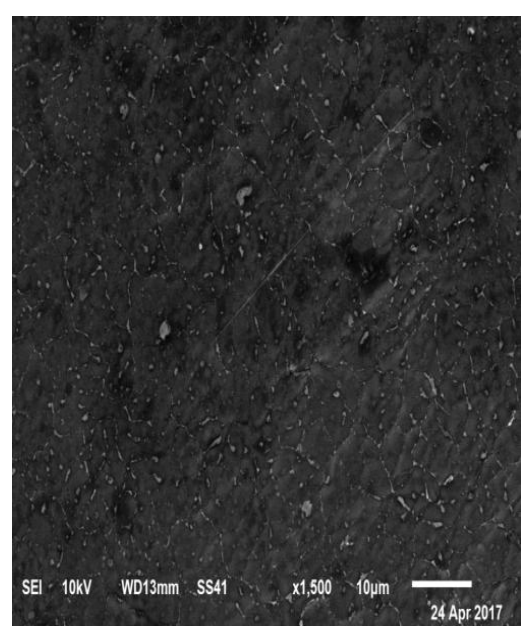

Al-0.1wt\%Zn-1.5wt\%Sn-1.63wt\%ln

(For $3 \mathrm{hr}$ ) (b)

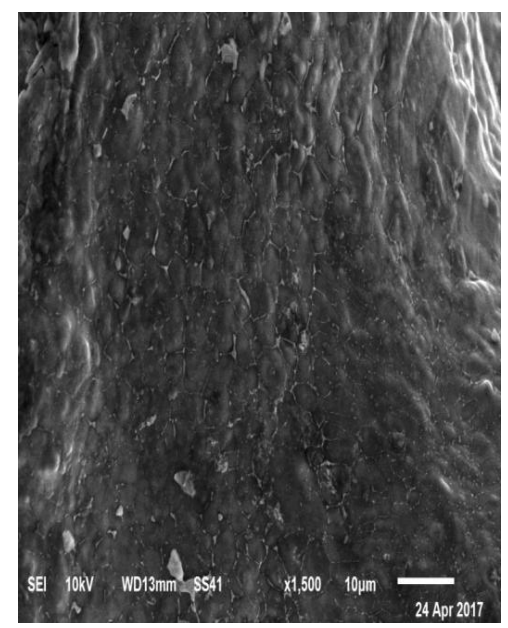

Al-0.1wt\%Zn-1.5wt\%Sn-1.63wt\%ln

(For $6 \mathrm{hr}$ ) (c)

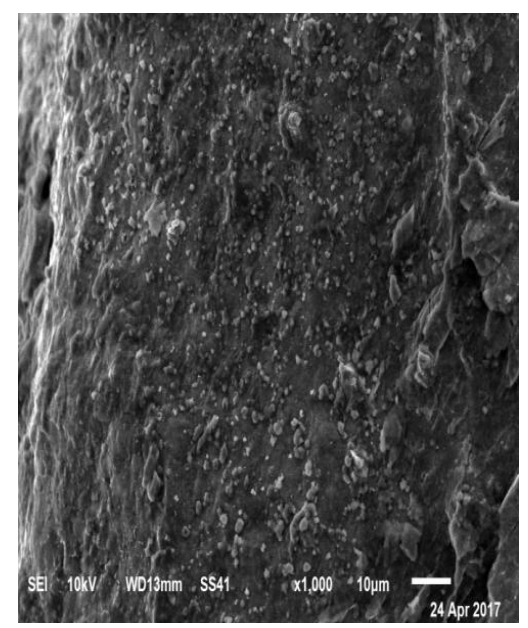

Al-0.1wt\%Zn-1.5wt\%Sn-1.63wt\%ln

(For $9 \mathrm{hr}$ )

Fig 6 : SEM micrograph of heat treatable free machining (a) Al-0.1Zn-1.5 Sn-1.63 In for 3hr ,(b) Al-0.1Zn-1.5 Sn-1.63 In for $6 \mathrm{hr}$, (c) Al-0.1Zn-1.5 Sn-1.63 In for $9 \mathrm{hr}$ alloys

\subsection{Melting Behavior}

$\mathrm{Zu}$ et al [16] suggested that structural changes take place to some extent in molten alloys as a function of temperature which have been confirmed by the corresponding calorific peak in a differential scanning calorimeter. The DTA curves obtained for alloys during heating with heating rate $10 \mathrm{~K} / \mathrm{min}$ are shown in Fig. 7 (a, b). The figure for all prepared alloys shows a single endothermic peak corresponding to the melting reaction. From this figure the melting point $\left(T_{m}\right)$, solidus temperature $\left(T_{s}\right)$, liquidus temperature $\left(T_{l}\right)$ and other thermal parameters (entropy $\Delta S$, enthalpy $\Delta H$, and specific heat $C_{p}$ ) of alloys are identified and then listed in Table (3). 


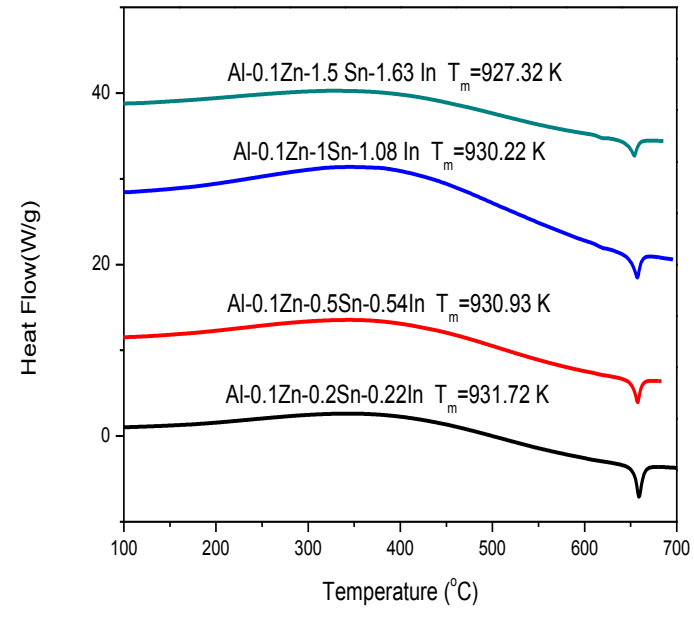

Fig 7a :Heating curves of free machining aluminum alloys

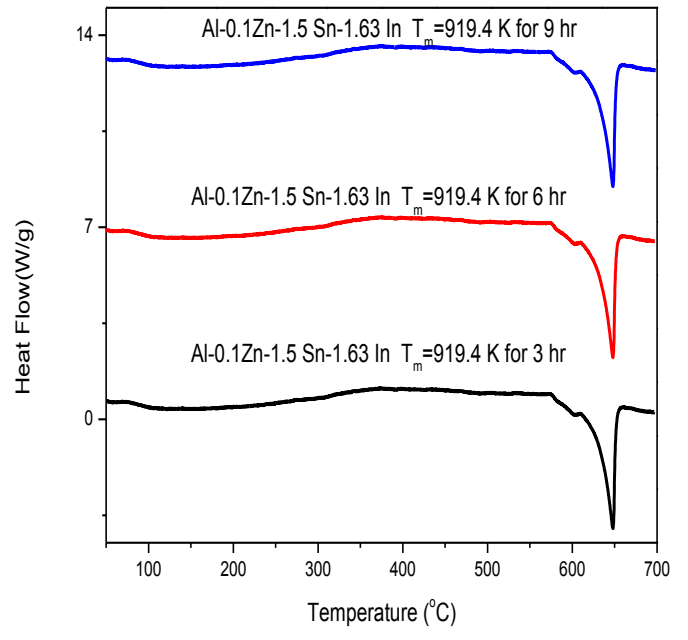

Fig $7 \mathrm{~b}$ :Heating curves of heat treatable free machining aluminum alloys at $262^{\circ} \mathrm{C}$

Table 3a. Thermal analysis of free machining aluminum alloys

\begin{tabular}{|c|c|c|c|c|c|c|}
\hline Melt-spun ribbons & $\mathbf{T}_{\mathbf{m}}(\mathbf{K})$ & $\mathbf{T}_{\mathbf{s}}(\mathrm{K})$ & $\mathbf{T}_{\mathbf{l}}(\mathrm{K})$ & $\begin{array}{c}\text { Enthalpy } \\
(\mathbf{j} / \mathbf{g})\end{array}$ & $\begin{array}{c}\text { Specific heat } \\
\mathbf{C}_{\mathbf{p}}(\mathbf{j} / \mathbf{k g} \cdot \mathbf{k})\end{array}$ & $\begin{array}{c}\text { Entropy } \\
\text { change (j/g.k) }\end{array}$ \\
\hline Al-0.1\%Zn-0.2\%Sn-0.22\%In & 931.72 & 926.42 & 950.37 & 208.5 & 8705.637 & 222.239 \\
\hline Al-0.1\%Zn-0.5\%Sn-0.54\%In & 930.93 & 924.29 & 942.44 & 125.9 & 6936.639 & 134.917 \\
\hline Al-0.1\%Zn-1\%Sn-1.02\%In & 930.22 & 921.39 & 942.29 & 171 & 8181.818 & 183.549 \\
\hline Al-0.1\%Zn-1.5\%Sn-1.63\%ln & 927.32 & 917.79 & 943.66 & 120.9 & 4673.367 & 129.931 \\
\hline
\end{tabular}

Table $3 b$.Thermal analysis of heat treatable free machining aluminum alloys at $262^{\circ} \mathrm{C}$

\begin{tabular}{|c|c|c|c|c|c|c|}
\hline Melt-spun ribbons & $\mathrm{T}_{\mathrm{m}}(\mathrm{K})$ & $\mathrm{T}_{\mathbf{s}}(\mathrm{K})$ & $\mathrm{T}_{\mathbf{l}}(\mathrm{K})$ & $\begin{array}{c}\text { Enthalpy } \\
(\mathrm{j} / \mathrm{g})\end{array}$ & $\begin{array}{c}\text { Specific heat } \\
\mathbf{C}_{\mathbf{p}}(\mathrm{j} / \mathbf{k g} \cdot \mathbf{k})\end{array}$ & $\begin{array}{c}\text { Entropy } \\
\text { change } \mathbf{j} / \mathbf{g . k})\end{array}$ \\
\hline $\begin{array}{c}\text { Al-0.1\%Zn-1.5\%Sn-1.63\%ln } \\
\text { (for 3 hr) }\end{array}$ & 919.4 & 905.07 & 920.9 & 37.59 & 2374.605 & 41.181 \\
\hline $\begin{array}{c}\text { Al-0.1\%Zn-1.5\%Sn-1.63\%ln } \\
\text { (for 6 hr) }\end{array}$ & 919.4 & 905.07 & 920.9 & 37 & 2337.334 & 40.534 \\
\hline $\begin{array}{c}\text { Al-0.1\%Zn-1.5\%Sn-1.63\%\%ln } \\
\text { (for 9 hr) }\end{array}$ & 919.4 & 905.07 & 920.9 & 37.1 & 2343.651 & 40.644 \\
\hline
\end{tabular}

The enthalpy of the system is determined by bonding between atoms, and entropy is determined by assemblage of relative positions of the atoms of the melt-spun ribbons used in this work. From the results of the thermal analysis it was found that the enthalpy content decreased as the enthalpy decreased for Al-Zn-Sn-In melt-spun ribbons.

\subsection{MECHANICAL MEASUREMENTS}

\subsubsection{Elastic Moduli And Tensile Properties}

The tensile test machine is most frequently performed to determine mechanical properties. Information on various tensile properties like proportional limit, elastic limit, yield point, yield strength, ultimate strength and modulus of elasticity is given in our article. Using tensile test machine for drawing stress-strain characteristic curve to calculate tensile strength, yield strength and elastic moduli and then listed in Table (4). 
Table 4a. Experimental values of elastic moduli and tensile properties of free machining aluminum alloys

\begin{tabular}{|c|c|c|c|c|c|c|c|c|}
\hline Alloy & $\begin{array}{c}\text { Tensile } \\
\text { strength } \\
\text { (MPa) }\end{array}$ & $\begin{array}{c}\text { Yield } \\
\text { strength } \\
(\mathrm{MPa})\end{array}$ & $\begin{array}{c}\text { Toughnes } \\
\text { s } \\
\left(\mathrm{J} / \mathrm{m}^{3}\right)\end{array}$ & $\begin{array}{l}\text { Critical shear } \\
\text { stress } \\
\text { csS(GPa) }\end{array}$ & $\begin{array}{c}E \\
(\mathrm{GPa})\end{array}$ & $\begin{array}{c}G \\
(\mathrm{GPa})\end{array}$ & $\begin{array}{c}\mathrm{B} \\
(\mathrm{GPa})\end{array}$ & $\begin{array}{c}\mathrm{H}_{\mathrm{v}} \\
(\mathrm{MPa})\end{array}$ \\
\hline $\begin{array}{c}\text { Al-0.1\%Zn- } \\
1.5 \% \text { Sn } 1.63 \% \mathrm{ln} \\
\text { (for } 3 \mathrm{hr} .)\end{array}$ & 918 & 809.5 & 27.5 & 9.27 & 179.6 & 66.3 & 204.9 & 483.5 \\
\hline $\begin{array}{c}\text { Al-0.1\%Zn-1.5\%Sn- } \\
1.63 \% \text { In } \\
\text { (for } 6 \text { hr.) }\end{array}$ & 873 & 688.3 & 34.9 & 6.5 & 133.3 & 49.2 & 152.1 & 531.6 \\
\hline $\begin{array}{c}\text { Al-0.1\%Zn-1.5\%Sn- } \\
1.63 \% \text { In } \\
\text { (for } 9 \text { hr.) }\end{array}$ & 1200 & 1004.0 & 48.0 & 9.29 & 182.4 & 67.4 & 208.1 & 471.8 \\
\hline
\end{tabular}

Table 4b. Experimental values of elastic moduli and tensile properties of heat treatable free aluminum machining aluminum alloys at $262{ }^{\circ} \mathrm{C}$

\begin{tabular}{|c|c|c|c|c|c|c|c|c|}
\hline Alloy & $\begin{array}{c}\text { Tensile } \\
\text { strength } \\
(\mathrm{MPa})\end{array}$ & $\begin{array}{c}\text { Yield } \\
\text { strength } \\
(\mathrm{MPa})\end{array}$ & $\begin{array}{c}\text { Toughness } \\
\left(\mathbf{J} / \mathbf{m}^{3}\right)\end{array}$ & $\begin{array}{c}\text { Critical } \\
\text { shear stress } \\
\text { (CSS) } \\
\text { (GPa) }\end{array}$ & $\begin{array}{c}\mathrm{E} \\
(\mathrm{GPa})\end{array}$ & $\begin{array}{c}\mathrm{G} \\
(\mathrm{GPa})\end{array}$ & $\begin{array}{c}\mathrm{B} \\
(\mathrm{GPa})\end{array}$ & $\begin{array}{c}\mathrm{H}_{\mathrm{v}} \\
(\mathrm{MPa})\end{array}$ \\
\hline $\begin{array}{c}\text { Al-0.1\%Zn- } \\
0.2 \% S n-0.22 \% \mathrm{ln}\end{array}$ & 875 & 677.2 & 32.8 & 7.24 & 144.5 & 53.4 & 163.2 & 310.7 \\
\hline $\begin{array}{c}\text { Al-0.1\%Zn- } \\
0.5 \% \text { Sn-0.54\%ln }\end{array}$ & 262 & 206.5 & 4.3 & 4.3 & 78.8 & 29.1 & 89.2 & 319.4 \\
\hline $\begin{array}{c}\text { Al- } 0.1 \% Z n-1 \% \text { Sn- } \\
1.02 \% \text { ln }\end{array}$ & 399.3 & 328.3 & 7.1 & 8.4 & 106.04 & 39.2 & 119.6 & 286.2 \\
\hline $\begin{array}{c}\text { Al-0.1\%Zn- } \\
1.5 \% \text { Sn-1.63\%ln }\end{array}$ & 777.8 & 672.3 & 26.6 & 8.32 & 161.8 & $\begin{array}{l}59.8 \\
\end{array}$ & $\begin{array}{l}184.6 \\
\end{array}$ & 254.02 \\
\hline
\end{tabular}

Table (4.a) lists the relationship between composition of tin and indium and tensile properties. It is shown that small amounts of tin and indium have some effect on mechanical properties of free machining aluminum alloys which enhances the tensile properties. It is cleared that a presence of large amount $\alpha$-Al rich phase causes the strengths resistant deformation increases. Consequently, the increase of resistant of deformation means the increase of strength. Also, Table (4.b) lists the relationship between composition of tin , indium and tensile properties of free machining aluminum alloys after heat treatment at $262 \mathrm{C}$ at different times 3,6 and $9 \mathrm{hrs}$. It is clear that the tensile properties, especially UTS, toughness and $\mathrm{H}_{\mathrm{v}}$ are improved and enhanced to max value at $9 \mathrm{hrs}$. Mechanical properties of Al-Zn-Sn-In free machining aluminum alloy are improved due to fine dispersion strengthening mechanism (partial size is less than $1 \mu \mathrm{m}$ ) which will impede grain boundary movement.
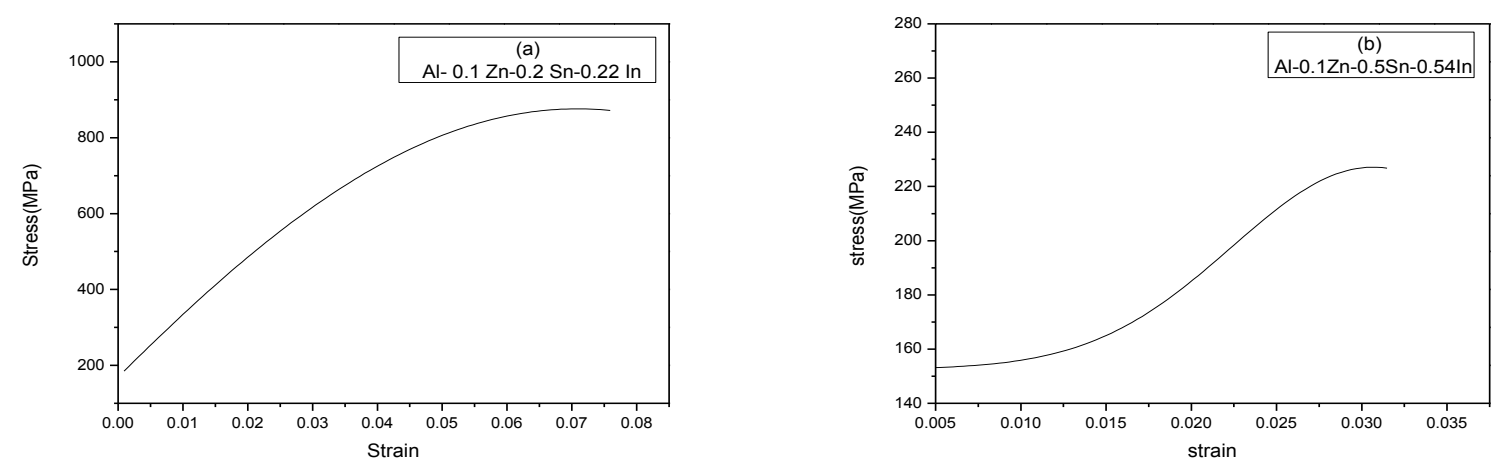

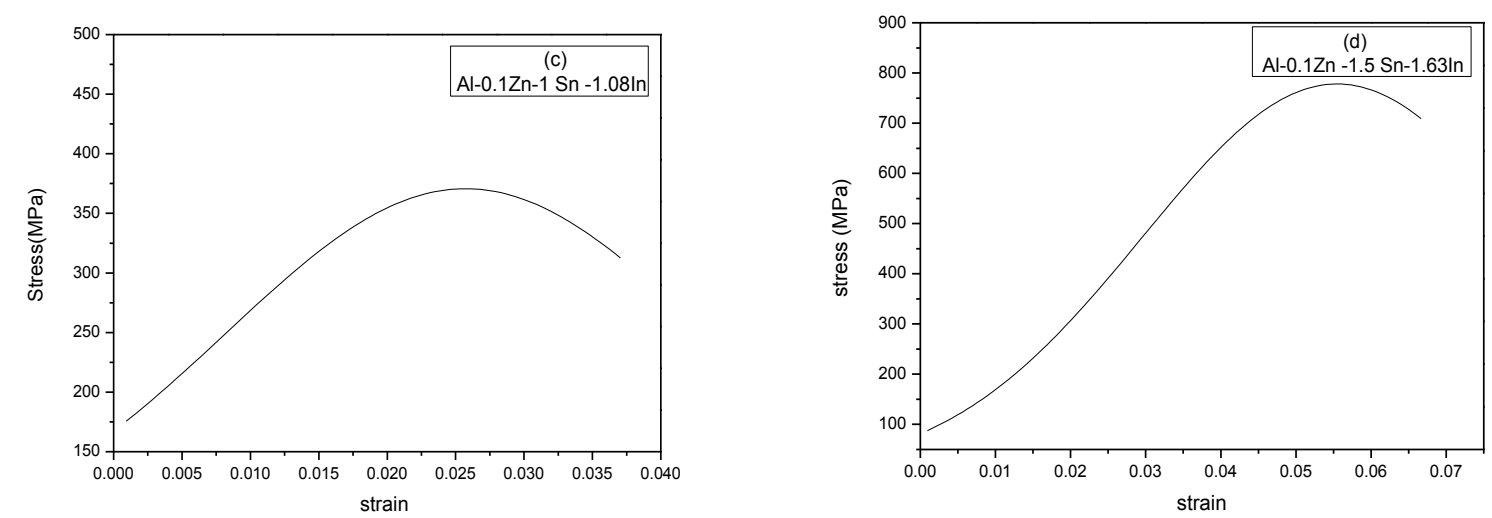

Fig 8: stress-strain characteristic curves of free machining (a) Al-0.1 Zn-0.2 Sn-0.22 In, (b) Al-0.1 Zn-0.5 Sn-0.54 In , (c) Al-0.1 Zn-1 Sn-1.08 In, (d) Al-0.1 Zn-1.5 Sn-1.63 In alloys
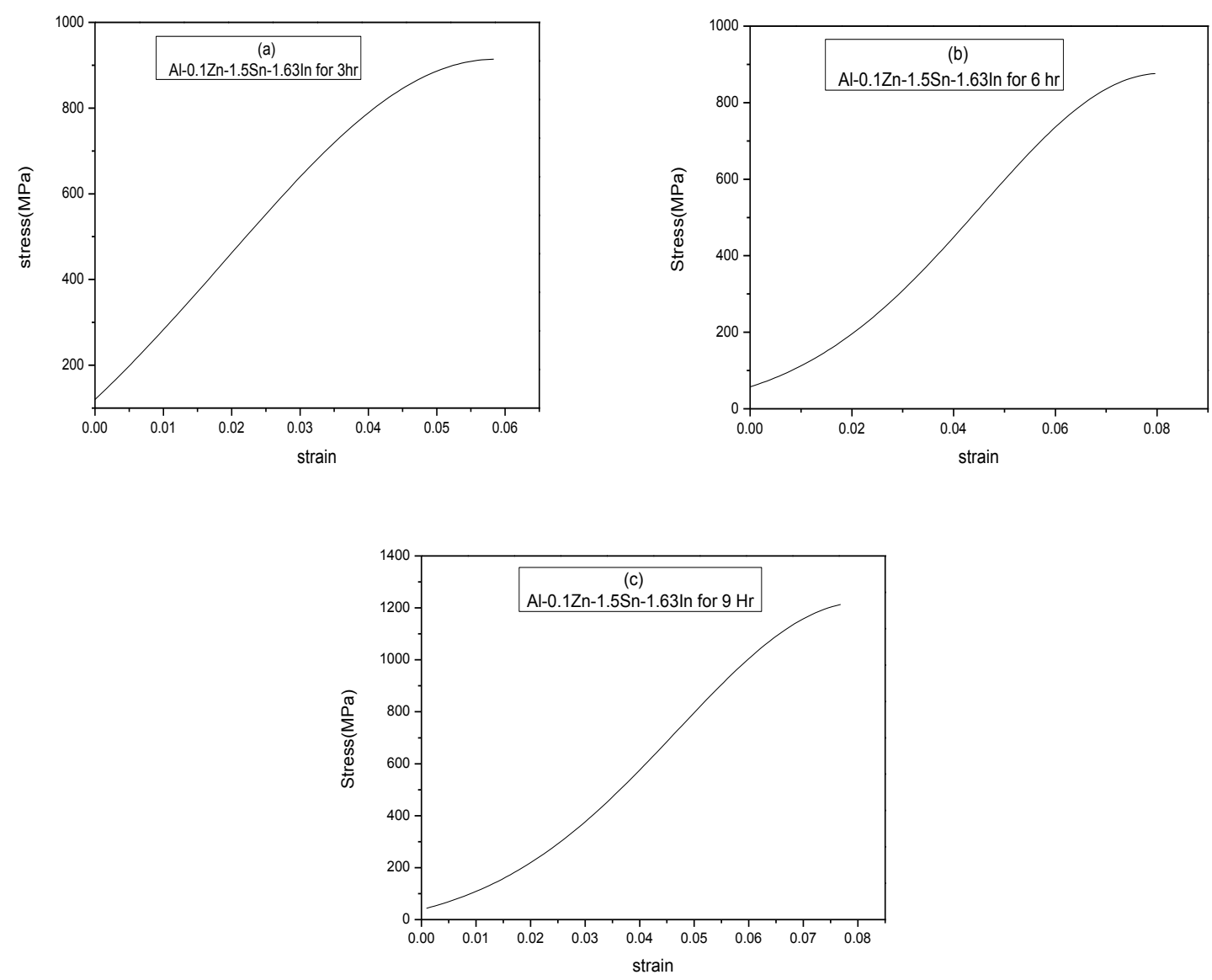

Fig 9: stress-strain characteristic curves of heat treatable free machining (a) Al-0.1 Zn-1.5 Sn-1.63 In for $3 \mathrm{hr}$,(b) Al-0.1 Zn-1.5 Sn-1.63 In for 6 hr,(c) Al-0.1 Zn-1.5 Sn-1.63 In for 9 hr alloys

The alloys after heat treatment transform from elastic-plastic behavior to plastic behavior showed in figure 8 . From the elastic moduli and stress-strain diagram in figure $(8,9)$ for all melt-spun ribbons obtained in this research, the critical shear stress (the minimum shear stress required to begin plastic deformation or slip) which acting on the slip plane at which the lattice becomes unstable. That is, the plastic deformation begins when the shear stress attains the value of the critical resolved shear stress as shown in fig $(8,9)$.

\subsubsection{Microhardness}

The mechanical properties of Al-Zn-Sn-In melt spun alloys can be determined by Vickers micohardness utilizing the standard Vickers formula, depending on literature of preceding studies [17, 18]. Table (4) lists the Vickers microhardness 
values of the melt spun Al-Zn-Sn-In alloys. The microhardness values increases as a result of dispersion strengthening. In addition, the hardness increases when the alloy is heated at $262{ }^{\circ} \mathrm{C}$ (i.e., due to formation of some precipitate from IMCs when heat treated. Also, the hardness increases as content of tin and Indium increases.

\section{CONCLUSIONS}

In this study, the structural, thermal, mechanical of the free machining Al-Zn-Sn-In ribbons rapid solidified from melt were investigated.

-The results showed that the melt spinning technique lead to enhancing the intermetallic compound formation (AIZn and $\mathrm{SnZn})$.

- Lattice distortions for aluminum phase in all the melt-spun ribbons are very low. This supports the optimum formation of face-centered cubic structure. Such configuration is inherently of lower energy and thereby more stable than a purely random arrangement of atoms.

- With the content of tin and indium increasing more, the microstructure becomes finer and its distribution becomes more homogeneous. The finer and more homogeneous microstructure leads to suitable effect on the mechanical properties of free machining aluminum alloys.

- Mechanical properties of Al-Zn-Sn-In free machining aluminum alloy are improved due to fine dispersions strengthening mechanism (partial size is less than $1 \mu \mathrm{m}$ ) which will impede grain boundary movement.

-After heat treatment at $262{ }^{\circ} \mathrm{C}$, it is clear that the tensile properties, especially UTS, toughness and $\mathrm{H}_{\mathrm{v}}$ are improved and enhanced to max value at $9 \mathrm{hrs}$.

-Critical shear stress values increased after heat treatment because the IMCs of AIZn and SnZn phase begins to appear and increase evidently after heat treatment.

-The microhardness values increases as a result of dispersion strengthening. In addition, the hardness increases when the alloy is heated at $262{ }^{\circ} \mathrm{C}$ (i.e., due to formation of some precipitate from IMCs when heat treated). Also, the hardness increases as content of tin and Indium increases.

-Melting temperature slightly changed and enthalpy increased after heat treatment due to presence of some precipitates of indium in the matrix.

Low density, suppression mechanical properties make Al-Zn-Sn-In free machining aluminum alloy attractive for industrial applications.

\section{REFERENCES}

[1] V. Songmene , R. Khettabi , I. Zaghbani , J. Kouom and A. Djebara, Machining and machinability of alluminium alloys, E'cole de technologie supe rieure (E`TS), Department of mechanical engineering ,1100 Notre-Dame street west , montreal Quebec H3C 1K3 ,Canada, WWW.intecho(en.com), 377-400.

[2] Bothroyd, G. 1975. Fundamentals of machining and machine tools, Scripta book co., Washington, DC .

[3] S. Koch and H. Antrekowitsch, Free -cutting aluminum alloy ,with Sn as substitution for lead ,278-281, BHM, 153. $2008 \mathrm{Jg}$. Heft 7.

[4] Smolej ,A. , B. Bresk Var , M. Sokovis , V. Dragojevic ,E. Slacck and T. Smoral, Properties of alluminium free-cutting alloys within, Part 1 . Aluminum 78 (2002) 4 , 284-288.

[5] Johne , D.1984. handbuch der aluminum zerspanung, aluminum - verlag , Düsseldorf .

[6] Sircar and S.Subhasish, Free machining aluminum alloy containing bismuth or bismuth-tin for free machining and a method of use, Reynolds metal company, Richmond, VA,US patent no. US 6 (2002) 409, 966 B1.

[7] Zoller , H. ,G.Enzler and J.C.Fornerod, über die zerspanbarkeit von aluminum le gieerungen , aluminum 45 (1969) 1 , 49-54.

[8] Johne , P. , sparen von aluminum wek-sotoffen, aluminum 56(1980) 6 , 413-417 .

[9] Trend , E.M., and R.K. Wright, 2000. metal cutting -fourth edition, Batterworth Hiene -man , Woburn.

[10] Edwards, B.J., and G.D. Scoh , 2004. Alcoa`s ultra-alloy 6020, A lead free aluminum alloy with A-rated machinability ideal suited for precision machined parts. Alcoa .

[11] M. Kamal, J. C. Pieri, R.Jouty, Memories et Etudes scientifiqes Revue de Metallurgie-Mars, 1983, $143-148$.

[12] Y.H.Zhu,Mater.Trans.45 , 3038 (2004).

[13] Y.A.Geller and A.G.Rakhshtadt,1977. Science of materials , vol.138 ,pp.138-141.

[14] P. Duwez, R.H. Willens, W. Klement, Continuous Series of Metastable Solid Solutions in Silver-Copper Alloys, J. Appl. Phys. 31 (1960) 1136.

[15] G. K. Williamson and W.H. Hall ,1953. Acta Metallurgica , Vol .1 ,22-31. 
[16] F. Q. Zu , Z. G. Zhu , B. Zhang , Y. Fengand and J. P.Schui ,2001. J.Phys. condens.matter ,13, 11435-11442.

[17] M. Yan ,W. Z. Zhu , B. Cantor, The microstructure of as-melt spun Al-7\% Si-0.3\% Mg alloy and its variation , continuous heat treatment, mater, Sci , Eng, A, 2000, $284,77-83$.

[18] O. Uzun , T. Karaaslan, M. Gogebakan and M. Keshin, Hardness and microstructural characteristics of rapidly solidified Al-8-16wt\% Si alloy , J. , alloys comp. , 376 , 2004, 149-157. 